\title{
A VALLOMÁSOK IGAZSÁGTARTAMÁT MEGHAMISÍTÓK TÍPUSAI ÉS VIZSGÁLATUK KIHALLGATÁSI HELYZETBEN \\ 3. rész, Az eltitkoló
}

\author{
Madzin András ${ }^{1}$, Alpek Alex², Bártfai Anna ${ }^{3}$, Kertesy Andrea ${ }^{4}$, Iványuk Áron ${ }^{5}$, \\ Benczúr Lilla ${ }^{6}$, Takács Szabolcs ${ }^{7}$, Kis György ${ }^{8}$ \\ ${ }^{1}$ ANIMA Polygraph Kft, LVA szakérto”, \\ 2,3,4,5 Károli Gáspár Református Egyetem, Pszichológia Intézet, hallgató, \\ ${ }^{6}$ klinikai szakpszichológus, \\ ${ }^{7}$ Károli Gáspár Református Egyetem, Pszichológia Intézet, egyetemi adjunktus, \\ ${ }^{8}$ ANIMA Polygraph Kft, Ügyvezető
}

\begin{abstract}
Absztrakt
Cikksorozatunkban annak a kutatómunkának az eredményiről számolunk be, amelyet 2014-ben kezdtünk - és jelenleg is tart.

Jelen cikkünkben egy olyan elbeszélő típust mutatunk be, mely elbeszélő kihallgatása során számos fals pozitív jelzést tapasztalhatunk: az eltitkoló esetében ugyanis olyan információk lehetnek a közlő birtokában, melyeket nem kíván megosztani. Azonban ez az információ aktuálisan nem is képezi részét a vizsgálatnak - erről viszont a kihallgatott nem tud. Így folyamatosan olyan jelzéseket fog a fogadó fél kapni, mely indokolatlanul kelti fel a gyanúját - tévútra vezetve így adott esetben a teljes kihallgatás folyamatát.

Vizsgálatunkban bemutatjuk, hogy bár valóban folyamatos jelzéseket lehet tetten érni az eltitkolónál, ezek a jelzések más csatornákon keresztül érkeznek, mint a valódi hazugok (meghamisítók és elhallgatók) esetében.
\end{abstract}

Kulcsszavak: hazugság • LVA • hangelemzés • tanúvallomás • tipológiák • eltitkolás

A kutatási engedély száma 278/2016/P. A vizsgálatban résztvevő összes vizsgálati alany írásban hozzájárult a hanganyagok és videóanyagok további kutatásokban és tudományos publikációkban való felhasználásához.

\begin{abstract}
We report about the results of a research work in these series of articles, which we have launched in 2014 and which continues on. In this article we introduce a narrative type, whose answers include number of false signals during interrogation: the secretive may possess such information which he or she wish not to share. However this information is not relevant to the actual investigation - but the secretive is not aware of this fact. So the interrogator - having these information - will receive signals which will raise suspicion - misleading the entire process of interrogation in this case. Our research is going to
\end{abstract}


present that the signals received from the secretive are transmitted on different channels than real lairs'.

Keywords: lie - LVA, speech analysis • deposition • secretive

Research license 278/2016/P. All participants signed a written document in which they declared: all audio and video records can be used for further researches and academic publications.

\section{BEVEZETŐ}

A hazugságkutatók - bár többféle, olykor egymástól jelentősen eltérő megállapításokra jutnak - jórészt egyetértenek abban, hogy hazugságról akkor beszélhetünk, ha

- a hazugnak szándékában áll a megtévesztést elkövetni, tehát tudatosan igyekszik a valós tényektől eltérő információkat átadni a fogadó félnek;

- a hazug számára tétet jelent e szándék sikerre vitele: vagy valamilyen számára negatív következményt (pl. büntetést) kerül el vele, vagy pedig közvetlen nyeresége származik a megtévesztésből;

- a hazug tudja, hogy kockázatot vállal megtévesztő cselekedetével.

Kísérleteinkben három hazug típust (meghamisító, elhallgató, titkoló), valamint egy „státusváltó” típust (patetikus) vizsgáltunk. Jelen cikkünk az eltitkoló típusra fókuszáló kísérleti eredményekról számol be.

A szakirodalom nem különíti el egymástól az eltitkoló és az elhallgató (leplező) típust. Többnyire ezt a két típust együtt kezelik, pedig a vizsgálatok, kihallgatások során komoly jelentősége van. A hazugságkutatással foglalkozó szakirodalom szinte mindegyike (Ekman, 2009; Vrij, 2012; Biland, 2009; De Paulo\& Matsumoto, 2011) figyelmeztet arra, hogy vannak olyan esetek, amikor az ártatlan is olyan jeleket közvetít a kihallgató felé, amit a hazugság jelének azonosítottak korábban.

Az LVA vizsgálatok tapasztalatai az egyes meghallgatott ${ }^{1}$ személyeknél a hangelemzés visszajelzéseinek magas kockázatára figyelmeztették az elemzőt. A meghallgatást követő interjúnak kiemelt jelentősége volt, mert az esetek többségében kiderült, hogy a meghallgatott személy az adott ügyben nem érintett, de életvitelében, vagy korábbi cselekedeteiben van olyan, amit az adott meghallgatáson nem szeretne feltárni. Ilyenek voltak a magánéleti problémák, szexuális orientáció, vagy egy korábban fel nem derített büncselekményben való részesség.

$1 \quad$ Ezekben az esetekben nem kihallgatás volt, hanem meghallgatás, interjú, vagy egy felvételi teszt alkalmazása az LVA-i-vel. 
Az LVA hangelemző technológiával való jelen kísérleteink adtak megoldást az eltitkoló megfigyelésére. A meghallgatás előtt egy előzetes interjút készítettünk a vizsgálati személlyel és részletesen elmondtuk azokat a kérdéscsoportokat, amelyeket fel fogunk tenni. Meggyőződtünk arról, hogy azokat a vizsgálati személy megértette és beleegyezését kértük ahhoz, hogy a feltevésre kerülő kérdésekkel egyetért, azok csak a vizsgált ügyhöz kapcsolódnak. Ezt követően az volt a tapasztalatunk, hogy megszüntek azok a fals jelzések, amelyek a vizsgált személy kockázatára mutattak.

A kutatási összefoglalóban (Kis et al., 2017) részletesen bemutattuk a maffiajátékot, valamint annak szerepeit. Az eltitkoló típust a maffiajáték során a felügyelők képviselik. Esetükben arról van tehát szó, hogy olyan információt tartanak vissza, melynek nincsen relevanciája a vizsgálat során (hiszen ők nyomoznak, nem ők a „rosszfiúk” a játékban). Azonban külön, többször felhívjuk rá a figyelmüket, hogy a kísérlet teljes időtarama alatt, így a tanúvallomások során is végig titkolniuk kell a kilétüket mindenki elől. Így - bár ők nem járnak tilosban, igyekeznek megvédeni a város polgárait - mégsem mondhatják el, hogy kik ők valójában! Ez a fajta eltitkolási kényszer jelenik meg esetükben feszültségként. E feszültség jeleit lehet tetten érni a hangjukban megjelenő változásokban. A külön instrukciók során nekik is titkolniuk kellett kilétüket a kihallgatók előtt, tehát az éjszakára vonatkozó kérdések során (bár ők felébrednek és a játékvezetőtől információt kérhetnek egy-egy játékosról) nem árulhatták el, hogy mit is tettek. Valamint esetükben a nappalok során a bizalmi kérdésekben sem mondhatták el például azt, hogy azért bíznak/nem bíznak bizonyos játékostársukban, mert a játékvezető tudatta velük az adott játékos szerepét.

Egy gyakorlati példával élve: az elkövetett bűncselekmények kihallgatásánál előfordul, hogy a gyanúsított el akarja titkolni a másságát. Egyrészt ezt nem akarja környezetével egyáltalán megosztani, mert számára ez akár egy őt kompromittálható adat lenne, másrészt abban bízik, hogy a kihallgatáson az előre megtervezett stratégiával ki tudja mosni magát a gyanúsítás tárgya alól. Ez azt jelenti, hogy folyamatosan meghamisítja a történetet a vizsgált ügy kapcsán, és az ártatlannak látszó kérdésekre is hazugságjeleket közvetít az őt kihallgató felé. A kihallgatási jegyzőkönyvek tanulmányozása és az LVA alkalmazása rámutat arra, hogy a közvetített jelzések mást mutatnak a meghamisítás és mást az eltitkolás esetében. Kísérleti eredményeink éppen ezeket az eltéréseket fogják bemutatni. 
Az LVA hangelemző technológia alkalmazásával egy olyan munkavállalónál alkalmaztunk egy kiválasztási tesztet, aki bizalmas pozíció betöltésére adta be önéletrajzát egy céghez. Előre elmondtuk, hogy az interjú során milyen kérdéscsoportok lesznek. Azokat a vizsgálati személy elfogadta és megértette. A teszt lefuttatása után a vizsgálatvezető több ponton is magas kockázatok mutatóira figyelt fel. Ezek olyan mértékű kockázatok voltak, melyekhez további információra volt szükség, annak érdekében, hogy megalapozott döntést tudjunk hozni. LVA 6.50 offline elemzéssel vizsgálódtunk tovább. Sikerült elkülöníteni, hogy mely szövegkörnyezetben (verbális tartalom csatornája) vannak hazugságra mutató jelzések. Az LVA 6.50 az Fmain, az FX, az S.O.S. ${ }^{2}$ kognitív stressz esetében adott figyelmeztető jelzéseket. Magas volt továbbá a hazugság stressz és a valószínúség is. A verbális tartalmat elemezve az LVA kockázati jelzései többnyire a korrupció témakörét tartalmazó kérdésekre adott válaszoknál jelentek meg. Arra a kérdésre, hogy a vizsgált személy bármilyen korrupciós cselekménybe tevőlegesen részt vett volna, nem kaptunk kockázati besorolásra mutató LVA jelzést. A vizsgálatvezető további kérdéseket tett fel, melyekből kiderült, hogy a vizsgálati személy az előző munkahelyén olyan környezetben dolgozott, ahol a cég vezetése alkalmazta a korrupciót. Erre a körülményre a vizsgált munkavállalónak teljes rálátása volt, amit el akart titkolni, mert félt attól, hogy ez a megpályázott pozíció betöltését veszélyezteti.

Esetünkben tehát eltitkolásról van szó - de nem a már említett, elhallgató szerinti értelemben (Czabán et al., 2017b). A titkoló esetében ugyanis elhallgatásra kerülnek információk, de nem arról a témáról, melyben információkat várunk tőle. Ez azt jelenti, hogy számos, fent már említett jelzést fog szolgáltatni nekünk (hang, verbális és nonverbális jeleket egyaránt), így esetünkben egy igen fontos szempont az, hogy miként tudjuk elkülöníteni egymástól az eltitkolót és az elhallgatót (előbbi minden, a témával kapcsolatos információt átad számunkra, míg utóbbi éppen vizsgálatunk tárgyában próbál elhallgatni részleteket).

Az adatok feldolgozásának módszertana megegyezett az első két részben (Czabán et al., 2017a, illetve Czabán et al., 2017b) tárgyaltakkal. Nevezetesen: az eredmények matematikai feldolgozásának alapját lásd Takács és társai (2017) cikkében, így erre külön nem térünk ki. A típusok összehasonlítására egy bootstrap eljárással kombinált varianciaanalízist alkalmaztunk (a bootstrap eljárást más pszichológiai vizsgálatokban is sikeresen lehet alkalmazni, lásd Marcinko et al., 2013). Bár az LVA paraméterekre a normalitás nem teljesült (Kolmogorov-Smirnov

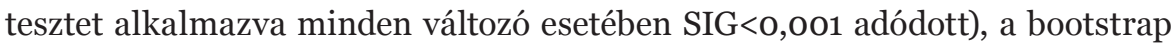
eljárás segítségével a csoportok közvetlen hibáját határoztuk meg - így a cso-

Paraméterek listáját lásd 49. olda 
portok összehasonlíthatókká váltak egymással (Efron \& Gong, 1983). A bootstrap eljáráshoz IBM SPSS 23.0 programcsomagot használtunk.

A normalitás hiánya miatt a varianciaanalízist rangvarianciaanalízis alkalmazásával is ellenőriztük (Kruskal-Wallis teszttel, illetve rang-Welch-próbával), a páros összehasonlításokhoz pedig Bonferroni korrekcióval elvégzett BrunnerMunzel (BM) tesztet használtunk. A sztochasztikus homogenitás-vizsgálatokhoz (lásd Vargha, 2005) a ROPstat programcsomagot alkalmaztuk. Az eredményeket itt is egyetlen táblázatban foglaljuk össze - és külön kiemeljük, hogy e csoport hol mutat lényeges eltéréseket minden más csoporthoz képest:

\section{1. táblázat}

Tipológiai sajátosságok - sztochasztikus dominancia mértéke az egyes paraméterek mentén

\begin{tabular}{|c|c|c|c|c|c|}
\hline & Dominancia' & BM & szabadsági fok & $\mathbf{p}$ & korrigált p \\
\hline Érzelmi szint & 0,321 & $-8,11$ & 178,4 & 0 & $0,0000^{* * *}$ \\
\hline Kognitív szint & 0,503 & 0,16 & 200,9 & 0,8719 & 1 \\
\hline Stressz szint & 0,633 & 5,33 & 167,8 & 0 & $0,0000^{* * *}$ \\
\hline Gondolkodási szint & 0,805 & 16,64 & 175,6 & 0 & $0,0000^{* * *}$ \\
\hline Közlési hajlandóság hiánya & 0,431 & $-2,79$ & 169 & 0,0058 & $0,0292^{*}$ \\
\hline Koncentráció & 0,507 & 0,29 & 175,2 & 0,7744 & 1 \\
\hline Párhuzamos gondolatok & 0,468 & $-1,32$ & 175,8 & 0,1899 & 0,9496 \\
\hline Egyenletesség & 0,469 & $-1,21$ & 170 & 0,2298 & 1 \\
\hline Zavarodottság & 0,477 & $-0,95$ & 174,1 & 0,345 & 1 \\
\hline Hazugság stressz & 0,625 & 5,6 & 182,7 & 0 & $0,0000^{* * *}$ \\
\hline Hazugság valószínűség & 0,57 & 2,87 & 175,3 & 0,0046 & $0,0229 *$ \\
\hline Kognitív szint & 0,603 & 4,84 & 195,3 & 0 & $0,0000^{* * *}$ \\
\hline Globális stressz & 0,603 & 4,17 & 171,3 & 0 & $0,0002^{* * *}$ \\
\hline Téma elutasítottsága & 0,465 & $-1,39$ & 171,2 & 0,1661 & 0,8303 \\
\hline Reakcióra való várakozás & 0,381 & $-5,84$ & 203,6 & 0 & $0,0000^{* * *}$ \\
\hline Gondolkodási arány & 0,587 & 3,26 & 164,5 & 0,0013 & $0,0067^{* *}$ \\
\hline Tudat alatti megismerési szint & 0,679 & 7,35 & 165,5 & 0 & $0,0000^{* * *}$ \\
\hline Elfojtott érzelmi szint & 0,474 & $-1,09$ & 177,3 & 0,2786 & 1 \\
\hline Képzelet, fantázia & 0,666 & 8,5 & 203,9 & 0 & $0,0000^{* * *}$ \\
\hline
\end{tabular}

3 Amennyiben a dominancia értéke szignifikánsan nagyobb o,5-nél, úgy az adott változóban az adott csoport szignifikánsan magasabb értékeket mutat a teljes populációnál. A szignifikánsan 0,5nél alacsonyabb értékek jelzik az adott csoport populációnál szignifikánsan alacsonyabb értékeit. 
Megfigyelhető, hogy számos ponton jelez itt is eltérést a hangelemzés, azonban fontos kiemelni azt, hogy ezek nem feltétlenül fals jelzések. Vegyük sorra, hogy a más valamit eltitkoló milyen tipikus sajátosságokkal bír a hangelemzési rendszer paramétereinek vizsgálata alapján:

- A stressz és a gondolkodási szint magas, kiemelkedő. Hasonlóan a hazugság stressz és valószínűség (mely fals jelzésnek tekinthető ebben az esetben), illetve a gondolkodási arány és a kognitív szint is mind magas.

A fenti eredmények azt jelzik, hogy a rendszer valóban fals pozitív eredményeket mutat. Azonban vegyük figyelembe azt, hogy emellett megjelenik egy, a korábbiakban nem tapasztalt magas érték is.

- A tudat alatti észlelés magas szintje és a képzelet magas szintje egyaránt jelen van az eltitkoló esetében.

E két eredmény alapján elmondható, hogy az eltitkoló esetében lényegesen nagyobb, magasabb stressz szinttel jár az egész kihallgatási helyzet. A vizsgált személy attól tart, hogy nem abban az ügyben kérdezik, amire ő számít (hiszen titkolnivalója van), és ez a folyamatos fenyegetettség nem képes elmúlni nála. Állandó várakozó állásponton van, mert nem érkeznek azok a kérdések, amelyek az ő eltitkolt témája felé terelnék a beszélgetést.

Emellett azonban két ponton is alacsony értéket mutat:

- a közlési hajlandóság hiánya alacsony, miként

- a reakciókra való várakozás is.

Megfigyelhető, hogy az eltitkoló szívesen beszél arról a témáról, amiről éppen kérdezik - de mellette folyamatosan azon gondolkodik, hogy a kihallgatás miként kötődhet az ő általa titkolt cselekményhez. A közlési hajlandósága a vizsgált ügyben magas, és nem vár az általa elmondottakra a kihallgatótól megerősítő visszajelzéseket. Miért is tenné? Esetében - az aktuális kérdésben - nincsen oka elhallgatásnak, meghamisításnak, tőle telhetően őszintén válaszol a feltett kérdésekre.

Az eltitkoló esetében a szerepe nagyfokú stresszel jár, mely abból fakad, hogy a kihallgatás egészében folyamatosan várakozó állásponton van: mikor térnek rá az ő eltitkolt cselekményére, melyről nem szeretne beszélni. Amíg ez nem történik meg, a feszültsége fennmarad - és ennek jelzései jelennek meg a nonverbális viselkedésben és a hangelemzés paramétereiben.

Azonban - szemben a valóban hazugságban lévő meghamisítóval és elhallgatóval - megjelenik az FX (párhuzamos gondolatok mutatója), ami a koncentráció szintjével van kapcsolatban és a Fmain (izgalmi szint és az elutasítás) paraméterével együtt vizsgálandó. Minél nagyobb a szám, annál szétszórtabb a vizsgált személy gondolkodása. Az említett paraméterek megjelenése jelezheti a szakértő számára, hogy itt valójában nem hazugságról, hanem egy másik ügyben való érintettségról van szó. 


\section{DISZKUSSZIÓ}

Az eddigi eredményekkel való összevetés fényében elmondható, hogy az eltitkoló esetében számos ponton fals eredményekre juthatunk: nem egy klasszikus értelemben vett hazugságról van szó (hiszen nem másítja meg számunkra a történetet és nem is leplezi azt), lásd például Ekman (2009) vagy Biland (2009) definícióit.

Azonban a különböző eszközök mégis jelezni fognak. Eredményeink azt igazolják, hogy ez az állapot jelentős mértékű stresszel jár együtt (globális stressz, kognitív stressz, érzelmi szint magas értékei), illetve egy folyamatos kognitív erőfeszítésre készteti a kihallgatott vizsgálati alanyt (gondolkodási szint, kognitív szint magas értékei).

Közlési hajlandósága irányunkban őszinte, az adott témáról szívesen beszél (reakciókra való várakozás alacsony, közlési hajlandóság magas) - de más valamit titkolni szeretne, melynek eredményeként minden kérdésünk, akciónk mögött okokat keres, sejt (tudat alatti folyamatok, párhuzamos gondolatok és fantázia, a képzelet magas szintje).

Az eltitkoló típusa az egyik olyan típus, mely éles helyzetek kihallgatását nagymértékben meg tudja nehezíteni. Gondoljunk arra, hogy egy bekövetkezett súlyos bűncselekménynél nagy tömegében kellene kihallgatásokat végeznünk (több száz vagy ezer bejelentés érkezik egy büneset kapcsán). Jelenleg az ilyen esetekben az idő nyomása nagy és a nyomozók igyekeznek felkutatni a tanukat és meghallgatni a bejelentőket. Ezekben az esetekben többnyire nem használnak LVA eszközt. Célszerü rögzíteni a hanganyagokat és utána az LVA technológia segítségével a meghallgatottakat tipológiák szerint elkülöníteni.

Az eltitkoló esetében az adott helyzetben a vizsgált ügyben ártatlan alanyokról van szó. Mégis: a folyamatos stressz és kognitív erőfeszítések miatt olyan szivárgások jönnek létre, melyek tévútra vezethetik a kihallgatókat.

Azonban, ha figyelembe vesszük az eddigi eredményeket (lásd Czabán et al., 2017a, illetve 2017b), úgy láthatjuk: a szivárgások más vonalak mentén jelentkeznek. Sem az elhallgató, sem pedig a meghamisító esetében nem volt például tetten érhető a tudat alatti folyamatok igen magas szintje, - tehát nem volt egy látens, amolyan búvó patakként meghúzódó, alternatív történet a háttérben. Ugyanis az elhallgató és a meghamisító esetében nincsen egyéb történet. Ök mindketten ugyanazon történetben vannak, melyet éppen kérdezünk tőlük.

Világos tehát, hogy a „búvópatakok” jelzéseinek tetten érése lehet a következő lépés a kutatás további fázisaiban: a videóelemzések során ezeket a jelzéseket igyekszünk pontosítani, hiszen a gyakorlatban nemcsak az a fontos, hogy tetten érjük azokat, akik hazudni próbálnak nekünk. Azt is fontos észre vennünk, ha valaki más okból küld hasonló jeleket, - hiszen például egy nyomozás során számos vakvágányt tudunk ezzel elkerülni. 
Eredményeink fényében elmondható: az eltitkoló bár folyamatosan küld számunkra jelzéseket, ezeket a megfigyelt csatornák más pontjain tudjuk tetten érni, mind akár az elhallgató, akár a megmásító esetében, így komoly esélyünk lehet arra, hogy a hangelemző rendszert használva elkülöníthessük őket (a fenti eredmények figyelembe vételével) a valódi elkövetőktől, illetve támogatóiktól.

\section{BIBLIOGRÁFIA}

Biland, C. (2009). A hazugság pszichológiája. Budapest: Háttér Kiadó Kft.

Efron, B., \& Gong, G. (1983): A Leisurely Look at the Bootstrap, the Jackknife, and Cross-Validation,

The American Statistician, Vol. 37 (1), 36-48.

Ekman, P. (2009). Beszédes hazugságok: A megtévesztés árulkodó jelei a politikában, az üzletben és a házasságban. Budapest: Kelly Kft.

Marcinko, D., Jaksic, N., Ivezic, E., Skocic, M., Surányi, Zs., Loncar, M., Francic, T., Jakovljevic, M.

(2013): Pathological Narcissism and Depressive Symptoms in Psychiatric Outpatients: Mediating

Role of Dysfunctional Attitudes, Journal of Clinical Psychology, 70(4), 341-352.

Vargha András (2005). Sokaságok összehasonlítása új módszerekkel, Statisztikai Szemle, 83, 429-448.

\section{Tematikus szám hivatkozott cikkei}

Kis, Gy., Takács, Sz., Liberman, A., \& Benczúr, L. (2017). A megtévesztés tipológiája - összefoglaló tanulmány. Psychologia Hungarica Caroliensis, 4(2), 2016. pp. 7-26.

Czabán, Cs., Alpek, A., Bártfai, A., Kertesy, A., Iványuk, Á., Benczúr, L., Takács, Sz., \& Kis, Gy.(2017a). A vallomások igazságtartamát meghamisítók típusai és vizsgálatuk kihallgatási helyzetben - 1 . rész, a meghamisító. Psychologia Hungarica Caroliensis, 4(2), 2016. pp. 27-35.

Czabán, Cs., Alpek, A., Bártfai, A., Kertesy, A., Iványuk, Á., Benczúr, L., Takács, Sz., \& Kis, Gy. (2017b). A vallomások igazságtartamát meghamisítók típusai és vizsgálatuk kihallgatási helyzetben - 2 . rész, Az elhallgató. Psychologia Hungarica Caroliensis, 4(2), 2016. pp. 36-43.

Takács, Sz., Kis, Gy., Makrai, B., \& Liberman, A. (2017). Tipológiákhoz tartozás varianciaanalízis alkalmazásával, LVA hangelemzés vertikális vizsgálat. Psychologia Hungarica Caroliensis, 4(2), 2016. pp. 79-93. 